\title{
Nudges Do Not Undermine Human Agency: A Note
}

\section{Citation}

Cass R. Sunstein, Nudges Do Not Undermine Human Agency: A Note, J. Consumer Pol'y (forthcoming 2015).

\section{Permanent link}

http://nrs.harvard.edu/urn-3:HUL.InstRepos:16149535

\section{Terms of Use}

This article was downloaded from Harvard University's DASH repository, and is made available under the terms and conditions applicable to Open Access Policy Articles, as set forth at http:// nrs.harvard.edu/urn-3:HUL.InstRepos:dash.current.terms-of-use\#OAP

\section{Share Your Story}

The Harvard community has made this article openly available.

Please share how this access benefits you. Submit a story.

Accessibility 


\title{
Preliminary draft 4/15/2015 \\ Forthcoming, Journal of Consumer Policy \\ All rights reserved
}

\section{Nudges Do Not Undermine Human Agency: A Note}

\author{
Cass R. Sunstein
}

\begin{abstract}
Some people believe that nudges undermine human agency, but with appropriate nudges, neither agency nor consumer freedom is at risk. On the contrary, nudges can promote both goals. In some contexts, they are indispensable. There is no opposition between education on the one hand and nudges on the other. Many nudges are educative. Even when they are not, they can complement, and not displace, consumer education.
\end{abstract}

We are in the midst of a period of growing official use of behaviorally informed approaches to public policy, spurred by broad receptivity to those approaches in many nations and across the standard ideological divisions (Halpern 2015; Sunstein 2013). In particular, many public officials been drawn to "nudges," such as information disclosure and warnings, in part because they preserve freedom of choice and avoid the costs and intrusiveness of mandates and bans. At the same time, those who are unfamiliar with the underlying concepts, and who are concerned about the possibility of abuse, have raised questions about potential risks to human agency and the freedom of consumers to choose as they wish.

My principal goal here is to explain that with appropriate nudges, neither human agency nor consumer freedom is at risk. On the contrary, nudges can promote both goals. In some contexts, they are indispensable. As we shall see, there is no opposition between

Cass R. Sunstein (四)

Robert Walmsley University Professor

Harvard University

Harvard Law School

1575 Massachusetts Ave

Areeda Hall 225

Cambridge, MA 02138

United States 
education on the one hand and nudges on the other. Many nudges are educative. Even when they are not, they can complement, and not displace, consumer education.

Nudges are interventions that steer people in particular directions but that also allow them to go their own way (Thaler and Sunstein 2008). A GPS nudges; a default rule nudges. A reminder is a nudge (Cadena and Schoar 2011; York and Loeb 2014); so is a warning. To qualify as a nudge, an intervention must not impose significant material incentives. A subsidy is not a nudge; a tax is not a nudge; a fine or a jail sentence is not a nudge. If an intervention imposes significant material costs on choosers, it might of course be justified, but it is not a nudge. Some nudges work because they inform people; other nudges work because they make certain choices easier; still other nudges work because of the power of inertia and procrastination.

A nudge might be defended on the ground that it either enlists or helps counteract a behavioral bias of some kind (such as present bias, availability bias, or unrealistic optimism). For example, some information campaigns attempt to counteract present bias by encouraging consumers to focus on the long-term. But a behavioral bias is not a necessary condition for a nudge. Disclosure of information can be helpful even in the absence of any bias (because unbiased people may lack information), and while inertia might fortify the effect of a nudge, it would be highly inaccurate to say that the basic point of nudging is "to exploit human biases." Nudges can respond to such biases, but even if people do not suffer from them, they can be helpful, in part because they can promote genuine (as opposed to merely formal) freedom of choice.

For example, a reminder (for example, that a bill is late) may respond to a bias (inattention), but it does not exploit a bias, and for reminders to be helpful, it is not necessary for people to suffer from unrealistic optimism. For consumers, a default rule simplifies life and might therefore be desirable whether or not a behavioral bias is involved. A GPS is certainly a nudge; it tells you how you can best get to your preferred destination, but it does not impose any sanction or costs if you refuse to do what it says. A GPS is useful even for people who do not suffer from any kind of behavioral bias.

As the GPS example suggests, many nudges have the goal of increasing navigability - of making it easier for consumers (and others) to get to their own preferred destination. Such nudges stem from an understanding that life can be simple or hard to 
navigate, and a goal of helpful choice architecture is to promote simple navigation (see the relevant findings in Bhargava et al. 2015). A GPS does not undermine human agency; it promotes it. The same point holds many of the most impressive strategies for facilitating interactions between human beings and machines. To date, there has been far too little attention to the close relationship between increased navigability and (good) nudges. Consumers often face multiple demands on their time and attention, and nudges can overcome the risk that they will overlook certain attributes of products or activities (Allcott and Sunstein 2015).

There is no opposition between consumer education and nudges, any more than there is an opposition between education and consumer finance regulation (which contains numerous nudges), or between education and contract law (which also contains numerous nudges, and did so long before the term came into common usage), or between education and the criminal law. Those who favor education and those who favor nudges have no quarrel.

It is essential to see that some form of choice architecture is inevitable. Human beings cannot wish it away, however much they are committed to free markets and consumers' freedom of choice. Any store has a design; some products are seen first, and others are not. Any menu places the options at various locations. Any website has a design, which will affect what and whether people will choose. Streets, street signs, computers, cell phones, and ballots offer choice architecture of their own. Television stations come with different numbers, and strikingly, lower numbers are better, even when the costs of switching are vanishingly low; people are more likely to choose a station numbered 2 or 3 than one numbered 150 or 200 .

Nor can public officials avoid nudging. A nation that respects freedom of speech and freedom of religion, or that is committed to human dignity, will nudge people by virtue of that very fact. Constitutional law itself has an expressive function, which influences people even when it does not coerce. A Bill of Rights imposes prohibitions on government, to be sure, but it also operates at least a bit like a GPS, providing public officials and citizens with important guidance about defining social commitments. Insofar as a Constitution safeguards freedom of speech, private property, or human dignity, it will help create a kind of choice architecture, and it will nudge. 
Any government, even one that is or purports to be firmly committed to consumer choice, free markets, and the idea of laissez-faire, will almost inevitably provide a set of prohibitions and permissions, including a number of default entitlements, establishing who has what before bargaining begins. The rules of contract, property, and tort provide a form of choice architecture for social ordering; they contain default rules as well as bans as authorizations. Such rules facilitate, signal, and prohibit, among other things - and this is quite important - through extinguishing some of people's self-help remedies, by forbidding people from "taking the law into their own hands." If someone has violated your contractual rights, or intruded on your property, or asserted property rights against you, you must resort to legally approved channels. This requirement is a mandate, and no mere nudge, but it too has an expressive function, helping to create preferences and values.

Default rules are omnipresent, and they help constitute the law of contract, much of which has the following form: Unless the contracting parties say otherwise, the rules that govern their relationship will be as follows; but the parties are permitted to say otherwise. People's legal relationships with their employer, their mortgage provider, their rental car company, their credit card company, and even their spouse and their children consist in large part of default rules. People can alter the default rules, to be sure, but often they do not, not least because of the power of inertia and suggestion (Sunstein, 2015b). The default rules will often operate like a GPS, or even help to shape preferences and values.

To some people, this is a disturbing or even threatening fact: They believe that people should be able to organize their lives as they like, and they are not at all enthusiastic about the idea that significant aspects of their lives are organized by default rules, which they did not themselves select, and which might well come from the practices, judgments, or wishes of other people. Nonetheless, that organization is in place. Moreover, it is true that some default rules are a product of traditions, customs, spontaneous orders, and invisible hands - a comfort to some people who especially distrust public officials. But it would be extravagant to say that all (or most) of them are. And even if they are, they will nudge individuals who live with them, and it takes real work to transform them into law, where they will have significant effects. 
Whenever a government has offices, designs highways, or maintains a court system and official websites, it will nudge. A government that maintains an educational system, or that imposes various incentives and requirements on educators, will certainly nudge. Any educational system is replete with nudges. Any effort to describe products, activities, and problems so that consumers can make sensible judgments (including sensible judgments about risks) will embed some kind of choice architecture. It is true that such architecture can (and should) insist on a great deal of room for freedom of choice. It should go without saying that active choosing and learning are important. It is also true that choice architects can at least aspire to important kinds of neutrality, fit for a free and self-governing society - including, for example, neutrality among religions, between men and women, and across political views. But choice architecture itself is inevitable. It cannot be wished away.

When sensible nudges are in place, human agency is retained (because freedom of choice is not compromised), and it is important to see that agency always takes place in the context of some kind of choice architecture. In evaluating concerns about human agency, we need to have a sufficiently capacious sense of the category of nudges, and an appreciation of the differences among them. As noted, some nudges combat behavioral biases but others do not, and even among those that do combat such biases, there are significant differences. A legitimate point about default rules may not apply to warnings or reminders. An ethical objection to the use of social norms may not apply to information disclosure.

If our concerns are consumer freedom and human agency (on grounds of either autonomy or welfare), and if we seek to avoid interventions that threaten them, our principal target should be mandates and bans. Nonetheless, it is true that the idea of nudging - and indeed the very word - might be taken to suggest impositions by some kind of elite, determined to steer people in the directions that it prefers. We can readily imagine nudges that would run afoul of this objection. But in a nation that is committed to both individual liberty and social welfare, those nudges are unacceptable. The problem with those nudges is not that they are nudges; it is that they reflect the imposition of an elite. It is pointless to object to nudges as such, just as it is pointless to object to contract law, food safety law, and criminal prohibitions as such. Desirable nudges should 
undermine neither autonomy nor welfare. On the contrary, they can promote both values; indeed, they might be indispensable for them.

Here as elsewhere, abstractions can be a trap. People tend to get carried away with them. Abstract concerns are important, but there is a real risk, which is that they will create confusion unless they are brought to bear on particular practices. In his Marginalia on Sir Joshua Reynolds, William Blake wrote, "To Generalize is to be an Idiot To Particularize is the Alone Distinction of Merit - General Knowledges are those Knowledges that Idiots possess." Characteristically, the great poet put it much too strongly. But he had a point. 
Author's Note: This essay draws on Nudges, Agency, and Abstraction: A Reply, Review of Philosophy and Psychology (forthcoming 2015). I am grateful to Tyler Cowen, Lucia Reisch, and Richard Thaler for valuable discussions.

\section{References}

Bhargava, S., Loewenstein, G., \& Sydnor, J. (2015). Do employees make sensible health plan decisions? Evidence from a menu with dominated options, (forthcoming).

Cadena, X., \& Schoar, A. (2011). Remembering to pay? Reminders vs. financial incentives for loan payments. National Bureau of Economic Research Working Paper No. 17020.

Halpern, D. (2015). The nudge unit: Inside the government department that changed our minds and saved us billions. London: W.H. Allen (forthcoming).

Sharot, T. (2011). The optimism bias: A tour of the irrationally positive brain. New York: Knopf Doubleday.

Sunstein, C. R. (2015a). Nudging and choice architecture: Ethical considerations. Yale Journal on Regulation, forthcoming.

Sunstein, C. R. (2015b). Choosing not to choose. Oxford: Oxford University Press.

Sunstein, C. R. (2015c). Fifty shades of manipulation. Journal of Behavioral Marketing (forthcoming).

Sunstein, C. R. (2014). Why nudge? The politics of libertarian paternalism. New Haven: Yale University Press.

Sunstein, C. R. (2013). Simpler: The future of government. New York: Simon \& Schuster. 
Sunstein, C. R., \& Reisch, L. A. (2014). Automatically green: Behavioral economics and environmental protection. Harvard Environmental Law Review, 38(1), 127-158.

Thaler, R. H., \& Bernartzi, S. (2013). Behavioral economics and the retirement savings crisis, Science, 339(6124), 1152-1153.

Thaler, R. H., \& Sunstein, C. R. (2008). Nudge: Improving decisions about health, wealth and happiness. New Haven: Yale University Press.

Wilkinson, T. M. (2013). Nudging and manipulation. Political Studies, 61(2), 341-355.

York, B. N., \& Loeb, S. (2014). One step at a time: The effects of an early literacy text messaging program for parents of preschoolers, National Bureau of Economic Research Working Paper No. 20659. 